\title{
ECO-COGNITIVE APPROACH TO THE INVESTIGATION OF EVALUATION CATEGORY
}

\section{Prihodko G. I.}

\section{INTRODUCTION}

Languages cannot exist and survive in a vacuum. They are the result of nonstop accommodation with the people who speak them and the surroundings in which they are used. An ecological approach to language displays that all cultures and related languages around the globe are sustained and protected both by various levels of well-organized relations that are obvious among language communities of speakers and the changeable quality of language itself ${ }^{l}$.

The ecological view has in recent years come a long way from its origins in biology, to become a new hypothesis within various branches. Its progress is holistic and focuses on dynamic, interactive systems and the interrelationships between the object of study and its context ${ }^{2}$. From an ecological point of view, language is inseparable from expressions of human sociality, such as communication, culture, and community.

Arising from this perspective are main notions, such as patterning, predictability, and creativity, which are suggested as the foundation of a very different approach to linguistics. Linguists, along with everyone interested in the many aspects of meaningful person's behavior, will find the ideas presented in this paper both motivating and challenging.

Any language is the product of steady adjustment to the persons who speak it and the environment in which it circulates ${ }^{3}$. The ecological approach to language covers the many-sided net of interactions which can be observed between reality, language and its users. The anthropocentric and eco-centric lines may be distinguished as rational forms in the advance of contemporary humanitarian sciences for the

1 Wendel J.N. Notes on the ecology of language. Bunkyo Gakuin university academic journal, 2005. 5, pp. 51-76. DOI:10.17265/1539-8072/2016.03.001

${ }^{2}$ Van Lier L. The ecology of language learning: practice to theory, theory to practice. Amsterdam: Elsevier Ltd., 2010. 260 p.

${ }^{3}$ Stibbe A. Deep ecology and language. The curtailed journey of the Atlantic salmon. Society and animals, 2006. 14 (1), pp. 61-77. 
reason that they create different interpretations in the research of human development and human activities effects.

All ecological concepts perceived by an individual have a definite value in our minds, that is, they can be assessed ${ }^{4}$. Evaluation is a primary constituent of cognition which is based on a value approach to the facts of nature and society. So, person's activity and life as a human being having different requirements, interests and objectives is impossible without estimation.

The aim of this paper is to demonstrate the eco-cognitive grounds of evaluation category. Achieving this purpose demands the resolution of the following tasks: the examination of the interconnection between ecolinguistics and evaluation and the analysis of the structure of the evaluation category.

Methods and techniques are determined by the purposes, theoretical direction of the proposed article and are of complex nature. They integrate the fundamental statements of Evaluation theory and Cognitive theory. Theses and techniques of eco-cognitive and biocognitive theories are used while studying the essential characteristics of the evaluation category.

\section{Ecology as an obligatory constituent of language}

Present-day linguistics is characterized by synchronization of different scientific views considering its main objective - language. In spite of the diverse interpretations of natural language principal directions, it is confirmed that it can be understood and elucidated only as a basic component of the cognitive system. It means that all language structures and instruments are aimed at ensuring cognitive and mental individual's activity.

In cognitive science the category of knowledge is considered to be the key one. It contains and incorporates information about the world and language system. This focus on linguistic investigation makes questions of clarifying linguistic semantics in terms of categorization and conceptualization of cognitive processes and procedures of outer world principally vital. In spite of the importance of the notion "Ecology", its

\footnotetext{
4 Killingsworth J. From environmental rhetoric to ecocomposition and ecopoetics: Finding a place for professional communication. Technical communication quarterly, 2005. 14 (4), p. 359-373. DOI: $10.1207 /$ s15427625tcq1404_1
} 
significant social role, it is not quite an object of research in linguistic papers. This determines the topicality of this piece of writing.

The foundation of the conceptual content of the linguistic ecology as a scientific field represents the essential value orientations related to ethical principles, concepts of morality, and spirituality. The subjects of linguistic ecology are the culture of thinking and speech behavior, construction of linguistic taste, defence and perfection of the literary language, identification of ways and methods of its enrichment, the clarity of speech habitat ${ }^{5}$.

Ecolinguistics as a scientific branch that unites ecology and linguistics investigates the contact between language, human being as a language individuality and the environment, which is the influence of the surroundings through the person and society on language, on the one hand and the influence of language on the moral and spiritual grade of society, on the other.

Language is viewed as a vital constituent of the chain connection between man, society and nature. Many investigations devoted to the consideration of cognitive and linguistic aspects of phenomena of environment and the essence of conceptualization and categorization as basic cognitive processes appeared in recent years.

The essential rules of cognitive field of the first generation were questioned, chief principles of cognitive science of the second generation (as it is conventionally named by G. Lakoff and M. Johnson) ${ }^{6}$ were worked out. Cognition is seen by scientists as the activities of the human body carried out in the course of interaction with the environment for adaptation to the environment for further survival and reproduction.

It is very significant to note that this idea and other postulates originated by G. Lakoff and M. Johnson were revealed in biocognitive theory developed by Chilean neurobiologists $H$. Maturana and F. Varela ${ }^{7}$. The scholars proposed a novel approach to living systems, based on the theory that living systems are studying systems, and life is a process of cognition.

5 Shevchenko I.S. The correlation of the informational and phatic functions a problem of ecolinguistics. Cognition, communication, discourse, 2015. 10 , pp. 114-132. DOI: https://doi.org/10.26565/2218-2926-2015-10-08

${ }^{6}$ Lakoff G., Johnson M. Metaphors we live by. London: University of Chicago Press, 2003. 193 p.

${ }^{7}$ Maturana H., Varela F. The tree of human understanding. Boston: Shambhala Publications, 1987. 269 p. 
In other words, an endeavour was made to find an explanation for the phenomenon of knowledge as an effective tool which enables a living organism to continue its existence in a certain environment. Moreover, the scientists highlight that the centre of any knowledge is an onlooker.

The onlooker is defined as a living system with a circular organization (for such a system U. Maturana uses the term "autopoetic"). All parts of the living system are imposed on this basic circularity and maintained it, ensuring its permanence in successive exchanges in the constantly changing environment. The living system exists as long as it retains the capability to self-reproduction and adaptation. As a result, reproduction and adaptation are the crucial conditions for a solitary organism's life and for the whole species.

Subjects surrounding the personality are an integral part of his niche, so relations with them serve the function of his adaptation within niches. These relations tend to have the nature of orientation. One organism can modify the behavior of another one, first, when they are linked with each other in such a way that the previous behavior of one determines the succeeding behavior of another, such as courtship or a battle, (such behavior is the basis for friendship and hostility).

Secondly, one organism can direct the behavior of another organism on part of his fieldwork, which is different from the part that incorporates this interaction. This takes place only if the interaction spheres of organisms are compatible. The second type of orienting interaction is the starting point for any language behavior.

The development of anthropocentrism in linguistics has contributed to the emergence of a new scientific direction - linguistic axiology, which studies the set of values of the ethnos and means of its representation in the language and cultural dimension. In the process of perception of the surrounding reality, an individual determines his approach to the world, assessing notions, facts, and events.

Considering the above mentioned, we can refer to the study of the role of evaluative phenomena in a human's life.

\section{Appraisal and values}

It is known that the fundamental nature of the category of evaluation is enlightened by the theory of value orientation of a person's activity and consciousness, and the variety of its characteristics embraces all that 
is given by the physical and mental nature of the man, his being and feeling $8,9,10$.

Assessment is a type of cognitive activity, as in epistemological terms, any cognitive act expresses the attitude of the speaker to the object described, that is, contains an act of estimation (Freeman, 2017, p. 43-53). The evaluative moment is nothing but a person's mental procedure held on the subject of the utterance (perception, understanding, synthesis, conclusion, etc.), which is an evaluation in its broadest sense.

All environmental phenomena perceived by a person have a definite value in our minds, that is, they can be assessed. Evaluation is an essential constituent of cognition, which is based on a value approach to the phenomena and objects of nature and society. So, person's activity and life as a human being having diverse needs, interests and goals is impossible without appraisal.

People evaluate their history and present times, appearance, behavior and manners of the individual, the shape and size of different subjects, things, duration and frequency of events, the level of complexity of tasks, etc. Evaluative explanation of circumstances and other issues is one of the most important types of mental-speech activity in everyday life of a human being.

As a result, the objective reality is examined by an individual from the angle of its evaluative character - good and evil, truth and falsehood, justice and injustice, benefit and harm, beauty and ugliness.

The origin of the concept of "value", if we resort to reconstructing it on the ground of the etymology of the words it is named, fixes in it at least three vital components: the characterization of the external properties of objects and things as phenomena of evaluative attitude to them; psychological qualities of the individual as a subject of this attitude; relationships between people, their communication, due to which values obtain a generalized meaning.

Each of the classes of values unites the basic meaning of value its material-objective, psychological and social importance. By recognizing the common properties of objects and reproducing their value, a person discloses certain characteristics of social relations because the

8 Ananko T. The Category of evaluation in political discourse. Advanced education, 2017. 8, pp. 128-137. DOI: 10.20535/2410-8286.108550.

9 Арутюнова Н.Д. Логический анализ языка. Адресация дискурса. Москва: Индрик, 2012. 511 с.

10 Вольф Е.М. Функциональная семантика оценки. Москва: Едиториал УРCC, 2009. $280 \mathrm{c}$. 
significance of a thing or phenomenon is determined mainly by the social attitude towards them.

There exist universal values (general to all mankind, specific to individual communities) and individual ones. Being a determined expression of the experience of the vital activity of a particular social community values form a certain structure, which a human being as a member of this society sticks to in the process of self-evaluation.

Personal values are an individual manifestation of group or universal and general values. They are somewhat special in different people, due to the explanation of their content and the transfer of emphasis. The choice, appropriation and adaptation of social values by an individual are arbitrated by his social identity and the values of the small contact groups referenced to him.

The subject of evaluation acts in these cases as a mental or physical receptor, evaluating episode, situation and object in different ways: ethical appraisal (embarrassing, humiliating, sinful), emotional (boring), intellectual (foolish), utilitarian (meaningless, late) and psychological (difficult, easy, not easy, wise). It highlights the most important quality of the semantics of evaluative words, their disperse meaning, chiefly due to the ability to represent and signify the assessment in terms of different grounds.

\section{Pragmatic and cognitive character of evaluation}

Human beings' activity is a pragmatic notion. It is proper only when it is aimed at those phenomena and properties from which it is possible to get something useful, constructive and valuable. The quintessence of evaluation is always related to the nature of a person, because we appraise only what is needed (physically and spiritually) to man and to Mankind.

Evaluation can be termed as the speaker's objective or subjective attitude to a definite object, which is explicitly or implicitly conveyed and expressed by language means ${ }^{11}$.

Assessment is always cognitive in its nature, and therefore logicalsubject. Evaluative and epistemological purposes of the language are closely interrelated and interconnected. In addition, they are equal, as in the course of estimation, cognition is transformed, and in the process of cognition, evaluation normally takes place.

11 Приходько Г. І. Категорія оцінки в контексті зміни лінгвістичних парадигм. Запоріжжя: Кругозір, 2016. 200 с. 
The correlation between cognition and evaluation is very multifaceted. It belongs to the domain of cognitive linguistics, the problems of which cover the essence of the procedures that control and form and structure speech perception. As a result, the cognitive approach based on the interaction of language and thinking is the most applicable for the study of the category of evaluation, because it investigates it in the context of human cognitive activity.

Appraisal is a process that is typical of any science. This is proved by the fact that value course in many cases donated to the progress of a whole range of directions not only in the linguistic sphere, but also in computer technology, genetic engineering, and many other fields.

It shows constant incorporation of scientific knowledge within the cognitive paradigm that was formed as interdisciplinary (cognitive) science.

The cognitive process of evaluation, counting in the general program of human activity, is decision-making-oriented, and is the source of the selection of practical actions. An individual as a subject of linguistic activity is a person who perceives and understands the world, and is competent of estimating speech facts in his day-to-day speech practice. The aesthetic experience of the personality is mainly recorded in the evaluative definitions of words.

The communicative objective put forward by the speaker is to convey to the listener his point of view, to persuade him of the possibility and legitimacy of exactly this, and not another idea of the word in the best possible way $^{12,13}$.

The image of the word, which is stored in the linguistic consciousness of the individual, is exposed in emotional and aesthetic assessments. This method is based on relations, caused by the fact reflected in the word, or by its sound shape.

Furthermore, by this time, V. Vinogradov's views that the word is shining with the expressive colors of the social surroundings have not lost their significance. The scholar wrote:

"By displaying the personality (individual or collective) of the subject of speech, characterizing his evaluation of reality, a word qualifies him

12 Prihodko G.I. Frame structure of the evaluative utterance. Messenger of Kyiv nationa linguistic university, 2019. 22 (2), p. 114-120. DOI: 10.32589/23110821.2.2019.192447

${ }^{13}$ White P. Evaluative contents in verbal communication. Verbal communication. A. Rocci, L. Saussure eds. Berlin: De Gruyter Mouton, 2016. pp. 77-96. DOI: $10.1515 / 9783110255478-006$ 
as a representative of a particular social group. Expression is always a subjective, typical and individual from the fastest to the most stable, from the excitement of the moment to the continuity not only of the person and her neighboring environment, class, but also of the epoch, nation, culture" $"$.

Evaluation is anthropocentric by its nature. While estimating an object or thing, an individual should "pass" its signs through his consciousness. The substance of the appraisal reflects the character of the person. Evaluation represents a person as an aim, showing the progress from the field of systems to the center of all these systems, to a person, as a language personality.

The close link between the speaker's evaluation and his knowledge of the world is validated by the fact that in the statement an appraisal can find its expression in the characterization and description of certain events, objects, phenomena that have a positive / negative evaluative importance for a particular social group or society as a whole.

The linguistic characteristics of the category of evaluation comprises the whole set of means and methods of its expression. They are phonetic, morphological, syntactic, mental, etc., which reflect the elements of the evaluative situation.

The stratification of evaluation vocabulary confirms A. Potebnya's statement about the parts of speech as a kind of "modus" illustration of something in our consciousness, as well as the ideas of some researchers on the necessity for a functional-cognitive approach to the study of the category of evaluation ${ }^{16,17,18}$.

The interest of scholars in the "grammar of evaluation" is stimulated by the characteristic for modern linguistics mood of attention to

14 Виноградов В.В. Русский язык (Грамматическое учение о слове). Москва: Наука, 2001. 601 с.

15 Потебня А.А. Из записок по русской грамматике. Москва: Просвещение, 1968. $551 \mathrm{c}$.

${ }^{16}$ Byessonova O. Reconstruction of value concepts in the language model of the world. Ferencik, M. \& Bednarova-Gibova, K. (Eds.), Language, literature and culture in a changing transatlantic world II. Part I: Lingustics, translation and cultural studies,2012. pp. 7-14.

17 Myroniuk T. Evaluative responses in modern English fiction. Advanced education, 2017. 8, pp.103-108. DOI: 10.20535/2410-8286.108550.

${ }^{18}$ Никитин М. В. Курс лингвистической семантики. СПб.: Изд-во РГПУ им. А.И. Герцена, 2007. 819 с. 
functional grammar, which reliably occupied its slot despite less than centuries-old history.

Functional orientation of estimating utterances is caused by the fact that the speaker makes the use of language means as a device for his own interference into a speech act, as an expression of his thoughts, opinions, judgments, his position and his estimation, the expression of relations he sets up between himself and the listener. It is the evaluativecommunicative function of the language, which is opposed to the representative (or conceptual) one. The speaker in this way expresses either the manifestation of the will or decision of the values of the phenomenon.

The functional principle allows considering evaluative utterances in their "actions", reflecting positive or negative values, attributed to the subject or the object of evaluation. Based on the tasks of functional grammar - the development of the dynamic aspect of functioning of grammatical units in interaction with components of different levels of language, which participate in expressing the meaning of the utterance, linguists try to explore comprehensively the semantics of evaluation and means of its expression in modern linguistic studies.

The explanation and interpretation of the evaluation as a "supersubjective" category of intellection and language reveals the difficult and incongruous nature of the evaluative semantics, which consists in generalizing reference of the evaluative task, "secondariness" of its nomination, the selection of the communicative goal, which reflects the objective properties of information simultaneously.

We can understand the evaluation as an expression of the evaluative attitude of the speaker to the subject of speech, achievable at all levels of the language, which is the result of abstract work of the speaker's consciousness and logical reasoning.

The notion of "evaluation" has become an essential part of the conceptual system of contemporary linguistics, which visibly displays the fact that it is impossible to study a language without resorting to its most important aim, its "creator", carrier, user, specific linguistic personality, a person.

The evaluation, for that reason, should be studied comprehensively and profoundly as a category of high level abstraction as one of the categories given by the social, physical and mental nature of a person, which determines his relation to other individuals and objects of the surrounding reality. 


\section{Results and discussion}

The states of activity of the nervous system, resulting from the contact with an object is qualified as basic representations ${ }^{19}$. Demonstrations of all possible connections with a particular object or with analogous objects as well as interactions with different objects (but at the same time and in similar situations) are combined into complex representations.

This multifaceted representation is regarded as a structural unit of the experience / memory, or concept. In other words, ecological concept is a set of illustrations of interactions with the object or objects (nonlinguistic and linguistic), characterized by the causal dependency and supports successful adaptation of the organism to its environment.

Based on this, the evaluation category is a complex cognitive phenomenon. In its structure the following components can be differentiated: a graded axiological scale of values, which correlates with events and facts of real world that are conceptualized, the linguistic means of expressing the results of this relation, two poles of appraisal positive and negative and the so-called equator of neutrality. The evaluation category acts as a filter of fixation of reality, that is, as an instrument of correlation of facts and events of reality with the graded axiological scale of the individual, resulting in evaluative judgment.

The structure of the evaluation category of a language can be represented as a nucleus, which is the custodian of the collective knowledge of a particular people, and a periphery that is filled by the subjective representations of the native speaker of that language.

The substance of the evaluative content is determined by the implementation of the central or peripheral characteristics. In the first case, collective knowledge is at the heart of a certain evaluative nomination. The correlation of the object with the periphery is based on subjective, individual knowledge.

The semantic field of the evaluation category can include many components. The comparative analysis of verbalization of evaluation category by means of different languages can solve the following very important task: to identify which constituents belong to the core of the concept, therefore, they are central and contain collective representations of speakers of the same language, and which are located on the periphery and are subjective ones.

19 Кравченко А.В. Знак, значение, знание: очерк когнитивной философии языка. Иркутск: Иркутская областная типография, 2001. 261 с. 
Features belonging to the core do not require explication and are understood by each native possessor of specific linguoculture. Peripheral characteristics are often conditioned by personal experience, individual perceptions of the speaker, and the pragmatic aspect of realizing the values, leading to the need for their explication through linguistic means.

During all his life a person cognizes surrounding reality, gains and increases new knowledge about the world, organizes and categorizes this information in a certain way and correlates it with the already known facts. Thus, the processes of conceptualization and categorization are of particular significance for systematization and updating the obtained knowledge, for its successful application and use in different situations.

Specific character of conceptualization is to comprehend the information received for the construction of mental objects and phenomena leading to the creation of certain beliefs about the world (concepts), while the categorization is a psychical act, that organizes, systematizes and sorts depictions of interactions in the person's mind, which diminishes the infinite diversity of the individual to visible number of units. Together they symbolize a complex mental process, aiming at the successful incorporation of a human being into the surrounding environment.

Conceptualization from the evaluative point of view is the appraisal of comprehension of objects of the world around us and the formation as a result of these assessment concepts in our mind. Evaluative categorization is a grouping of objects and phenomena by the nature of their assessment according to the evaluative classes and categories, as well as the mental correlation of an object with a certain evaluative category.

The purpose of the evaluative concepts is to provide a vision for the categories and to serve as a cognitive basis for their formation is largely determined by the system of quantitative and individual values of a person. The specificity of evaluative categorization and its main difference from natural categorization is that these two processes are based on different ways of perceiving the world, natural and evaluative pictures of the world.

Each individual has a unique experience of adaptation to the environment; consequently, the set of representations and concepts of causal relations is also to some extent unique. In this connection, it is possible to speak about the individual level in the structure of the concept. However, a person lives in a certain society, which is a part of his niche.

The existence of an individual directly depends on the contacts with other individuals, as they orientate him on his effective behavior in a 
definite situation. In this regard, it is possible to speak about social and national levels of concept. Regardless of the great variety of niches, some objects are common to all, such as macro-niche "Earth". Conceptsuniversals are the result of interactions with such objects.

Cognitive prototypes that exist in the person's mind, are different according the channels of incoming information, or, in terms of the biological approach, they are formed because of diverse kinds of interactions with constituents of the niche. Thus, we can differentiate the concepts of sensory perception of the world and concepts of mediate knowledge.

The major characteristic of the human's mind is a facility to react not only to direct motivation, but also to the sound stimulus - a word. Due to the language, a person perceives and feels the outer reality in a different way than an animal - he studies it in the course of communication. From the point of view of the biological conception of language, its chief function is to enlarge the cognitive field or the area of individual's interrelations.

Speaking about eco-cognitive approach to the analysis of the evaluation concept it is necessary to refer to the notion of meaning.

Meaning is the causal connections linking the representations of interaction with the linguistic and non-linguistic objects in the mind of the person. Linguistic behavior of people forms a component of the environment, being the existential sphere.

Relation of mutual causality between the human being and the environment requires causal relations between the state of his nervous system (consciousness) and language as a social adaptive behavior. Consequently, the analysis of the meaning of language units helps to classify relatively authentic structure of concept.

According to the unified eco-cognitive hypothesis of meaning, an inherent feature of living systems is the gift to generate meaning. Meaning is the link between the organism and environment, defined by the value that some pieces of the environment have for this very organism. Such meaning can be considered as an ecological one, in the sense that it is not totally subjective or objective, but is determined by the interaction between the organism and the surroundings.

From the position of eco-cognitive approach, conceptual worldview can be defined as the complex of concepts or multifarious representations present in the mind of the individual reflecting the collective experience of the direct and indirect (in the process of upbringing and education) relations with the environment. This conceptual system itself is the object of interaction. 
Linguistic ecology dynamically reveals natural alternations of linguistic conceptualization of the world, the interactions between social, cultural and linguistic processes. In this regard, it should be noted that this area has brightly marked interdisciplinary character, integrating varied knowledge of humanitarian nature $\mathrm{e}^{20}$.

A great amount of interdisciplinary phenomena and their respective terms functions in linguistic ecology. They are in a state of constant contact and intersect with different linguistic fields of terms. Hence, linguistic ecology relates to the branch of compound and multifaceted notions of culturological and humanitarian character.

\section{CONCLUSIONS}

The category of evaluation is an important component of the conceptual worldview, as far as the notions of positive and negative, good and evil, beauty and ugliness, intelligence and dullness, hard work and laziness, moral and immoral are inherent in any culture, any social system.

At the same time, in the mind of the native speaker of each language, the image of the world is created by a set of linguistic universals and special functioning of linguistic signs that reflect the national viewpoint.

Language worldview is a symbolic way of understanding objects of reality in which the important fragments of the world are fixed. In this case, the objective world itself, and judgments about it, its evaluative characteristics and subjective attitude to it by members of this society are represented in the interaction of the means of language expression.

So, we regard the evaluation concept as an independent mental formation that is culturally specified. Being verbalized, this concept is considered to be a part of the conceptual and language worldview of a certain linguocultural community, and can be defined as their structural component. The reason for this is that the evaluation, being a factor inherent in any culture, participates in shaping the value worldview.

\section{SUMMARY}

This paper discusses the eco-cognitive foundations of evaluation category. It examines the peculiarities of language research approaches as an instrument of harmonious lifestyle of the people as well as an important means of creation of evaluative worldview. The aim of this

20 Wijayanto A. An Ecolinguistic perspective on the languages used by a Javanese in Banjarmasin-South Kalimantan (a case study). Kajian linguistik dan Sastra, 2005. 15 / 29, pp. 80-92. DOI: https://doi.org/10.23917/kls.v19i1.4406 
paper is to demonstrate the eco-cognitive grounds of evaluation category. The article grounds on theses and techniques of Evaluation, Cognitive, Eco-cognitive and Biocognitive theories.

Ecolinguistics as a research field that combines ecology and linguistics studies the interaction between language, human being as a language personality and his environment. The anthropocentric and ecocentric lines may be distinguished as reasonable forms in the development of contemporary humanitarian sciences for the reason that they establish different interpretations in investigating development and outcomes of human activity.

Axiological aspect of natural environment preservation has contradicted the anthropocentric outlook, as a result the principles of ecological ethics are thought to be much more important for the issue of human survival than anthropocentric ideals of value.

Evaluation is a fundamental constituent of cognition, which is based on a value approach to the facts of nature and society. So, person's activity and life as of a human being having different requirements, interests and objectives is impossible without estimation.

The paper looks at the evaluation category as the formation which consists of a nucleus, which is the custodian of the collective knowledge of a particular people, and a periphery that is filled by the subjective representations of the native speaker of that language. The evaluation category is an independent mental formation that is culturally specified. It is considered to be a part of the conceptual and language worldview of a certain linguocultural community, and can be defined as their structural component.

\section{References}

1. Wendel J.N. Notes on the ecology of language. Bunkyo Gakuin university academic journal, 2005. 5, pp. 51-76. DOI:10.17265/15398072/2016.03.001

2. Van Lier L. The ecology of language learning: practice to theory, theory to practice. Amsterdam: Elsevier Ltd., 2010. 260 p.

3. Stibbe A. Deep ecology and language. The curtailed journey of the Atlantic salmon. Society and animals, 2006. 14 (1), pp. 61-77.

4. Killingsworth J. From environmental rhetoric to ecocomposition and ecopoetics: Finding a place for professional communication. Technical communication quarterly, 2005. 14 (4), p. 359-373. DOI: $10.1207 /$ s15427625tcq1404_1 
5. Shevchenko I.S. The correlation of the informational and phatic functions a problem of ecolinguistics. Cognition, communication, discourse, 2015. 10, pp. 114-132. DOI: https://doi.org/10.26565/22182926-2015-10-08

6. Lakoff G., Johnson M. Metaphors we live by. London: University of Chicago Press, 2003. 193 p.

7. Maturana H., Varela F. The tree of human understanding. Boston: Shambhala Publications, 1987. 269 p.

8. Ananko T. The Category of evaluation in political discourse. Advanced education, 2017. 8, pp. 128-137. DOI: 10.20535/24108286.108550.

9. Арутюнова Н.Д. Логический анализ языка. Адресация дискурса. Москва: Индрик, 2012. 511 с.

10.Вольф Е.М. Функциональная семантика оценки. Москва: Едиториал УРСС, 2009. 280 с.

11.Приходько Г. І. Категорія оцінки в контексті зміни лінгвістичних парадигм. Запоріжжя: Кругозір, 2016. 200 с.

12.Prihodko G.I. Frame structure of the evaluative utterance. Messenger of Kyiv nationa linguistic university, 2019. 22 (2), p. 114-120. DOI: 10.32589/2311-0821.2.2019.192447

13. White P. Evaluative contents in verbal communication. Verbal communication. A. Rocci, L. Saussure eds. Berlin: De Gruyter Mouton, 2016. pp. 77-96. DOI.: 10.1515/9783110255478-006

14.Виноградов В.В. Русский язык (Грамматическое учение о слове). Москва: Наука, 2001. 601 с.

15.Потебня А.А. Из записок по русской грамматике. Москва: Просвещение, 1968. 551 с.

16. Byessonova $\mathrm{O}$. Reconstruction of value concepts in the language model of the world. Ferencik, M. \& Bednarova-Gibova, K. (Eds.), Language, literature and culture in a changing transatlantic world II. Part I: Lingustics, translation and cultural studies, 2012. pp. 7-14.

17. Myroniuk T. Evaluative responses in modern English fiction. Advanced education, 2017. 8, pp.103-108. DOI: 10.20535/24108286.108550 .

18.Никитин M. В. Курс лингвистической семантики. СПб.: Изд-во РГПУ им. А.И. Герцена, 2007. 819 с.

19.Кравченко А.В. Знак, значение, знание: очерк когнитивной философии языка. Иркутск: Иркутская областная типография, 2001. $261 \mathrm{c}$. 
20. Wijayanto A. An Ecolinguistic perspective on the languages used by a Javanese in Banjarmasin-South Kalimantan (a case study). Kajian linguistik dan Sastra, 2005. 15 / 29, pp. 80-92. DOI: https://doi.org/10.23917/kls.v19i1.4406

Information about the author: Prykhodko Ganna Illivna, Doctor of Philological Sciences, Professor, Professor at the Department of English Philology

Zaporizhzhia National University 66, Zhukovsky str., Zaporizhzhia, 69600, Ukraine 